\title{
Upaya Meningkatkan Pemahaman Bahaya Bullying Melalui Bimbingan Klasikal pada Siswa
}

\author{
Ade Novera Prahardika \\ MTs Tanbihul Ghofilin \\ Bawang Mantiranom Banjarnegara, Banjarnegara, Jawa Tengah, Indonesia \\ Ve_syaira@yahoo.com
}

\begin{abstract}
Bullying happens in schools can disrupt student learning in school. The school counselor in particular have an important role to enable the students to avoid acts of bullying so that they can learn effectively and efficiently. The students who have an understanding of the dangers of bullying will have a better chance to avoid bullying than students who do not have an understanding of the dangers of bullying. This study aims to investigate the dangers of bullying through increased understanding of classroom guidance on eighth grade students of SMP Muhammadiyah 3 Yogyakarta Academic Year 2012/2013. The results showed that after being given a classical guidance services, understanding the dangers that are in the category of very high that the number of frequency of 23 by 71, 875\%. In the category of very high already reached more than half the number of students. In the high category with a number of frequencies $6,18,75 \%$, moderate category frequency number 3 for $9,375 \%$, the low category number 0 of $0 \%$, the category of very low with the number of frequencies 0 of $0 \%$. Thus, it can be concluded that the classical guidance is effective and innovative strategies to improve the understanding of eighth grade students of SMP Muhammadiyah 3 Yogyakarta on understanding the dangers of bullying. The results of this study can be used as reference material for the teacher guidance and counseling to improve understanding of the dangers of bullying on students through classical counseling services in schools.
\end{abstract}

Keyword: bullying, classroom guidance

Bullying yang terjadi di sekolah dapat mengganggu siswa belajar di sekolah. Pihak sekolah khususnya guru bimbingan konseling memiliki peran yang penting agar para siswa terhindar dari perbuatan bullying sehingga mampu belajar secara efektif dan efisien. Para siswa yang memiliki pemahaman mengenai bahaya bullying akan memiliki peluang lebih besar untuk terhindar dari tindakan bullying dari pada siswa yang tidak memiliki pemahaman bahaya bullying. Penelitian ini bertujuan untuk mengetahui adanya peningkatan pemahaman bahaya bullying melalui bimbingan klasikal pada siswa kelas VIII SMP Muhammadiyah 3 Yogyakarta Tahun Ajaran 2012/2013. Hasil penelitian menunjukkan bahwa setelah diberi layanan bimbingan klasikal, pemahaman bahaya berada pada kategori sangat tinggi yaitu dengan jumlah frekuensi 23 sebesar 71, 875 \%. Dalam kategori sangat tinggi sudah mencapai lebih dari setengah jumlah siswa yang ada. Pada kategori tinggi dengan jumlah frekuensi 6 sebesar 18, $75 \%$, kategori sedang jumlah frekuensi 3 sebesar 9, $375 \%$, kategori rendah jumlah 0 sebesar $0 \%$, kategori sangat rendah dengan jumlah frekuensi 0 sebesar $0 \%$. Dengan demikian, dapat disimpulkan bahwa bimbingan klasikal merupakan strategi yang efektif dan inovatif untuk meningkatkan pemahaman siswa kelas VIII SMP Muhammadiyah 3 Yogyakarta mengenai pemahaman bahaya bullying. Hasil penelitian ini dapat dijadikan sebagai bahan rujukan bagi guru bimbingan dan konseling untuk meningkatkan pemahaman bahaya bullying pada siswa melalui layanan bimbingan klasikal di sekolah.

Kata Kunci: bullying, bimbingan klasikal

\section{Pendahulan}

Dasar pertimbangan atau pemikiran tentang penerapan program bimbingan dan konseling di sekolah, bukan semata-mata terletak pada ada tidaknya landasan hukum atau ketentuan dari pemerintah. Namun yang lebih penting adalah adanya kesadaran atau komitmen untuk memfasilitasi siswa agar mampu mengembangkan potensi dirinya atau mencapai tugas-tugas perkembangannya. Di sekolah yang terdiri dari berbagai karakter siswa, tak jarang terjadi suatu perbedaan pendapat, permusuhan dan lain sebagainya untuk itu bimbingan dan konseling mengambil peran dalam hal ini, khususnya agar pendidikan mampu berjalan secara efektif dan efisien.

Sekolah yang merupakan tempat terselenggaranya proses pendidikan ternyata tidak semata-mata dijadikan tempat untuk belajar mengajar. Penyimpangan perilaku kekerasan seperti tawuran, berkelahi dan lain sebagainya 
justru banyak dilakukan dan berawal di sekolah. Fenomena kekerasan antar siswa ini ditemukan pada hampir seluruh sekolah dari jenjang taman kanak-kanak hingga sekolah lanjut tingkat atas. Namun kesadaran sekolah untuk menanggulangi hal tersebut masih sangat rendah. Hal ini sangat ironis, karena sekolah yang seharusnya menjadi tempat yang aman dan nyaman untuk belajar harus dinodai dengan penyimpangan perilaku seperti kekerasan. Hal lain yang lebih ironis adalah kekerasan yang harusnya semakin lama semakin berkurang justru saat ini kekerasan semakin bertambah.

Sesuai dengan peraturan pemerintah dan kebijakan-kebijakan sekolah yang mengatur pendidikan, siswa memiliki hak untuk merasa aman dan memperoleh pendidikan. Tetapi nampaknya peraturan-peraturan yang ada tidak berjalan dengan baik, sehingga masih banyak kasus-kasus kekerasan atau penyimpangan lainnya yang tidak diselesaikan atau bahkan dibiarkan begitu saja. Hal ini dibuktikan dengan adanya kasus bunuh diri yang terjadi pada siswa akibat ulah temannya yang selalu menghina dan menganiayanya, kasus kekerasan ini banyak diberitakan pada beberapa surat kabar. Penanganan kasus ini menyadarkan banyak pihak, sayangnya banyak pihak yang tersadar setelah adanya korban. Jika peraturan dan kebijakan yang telah ada dijalankan dengan baik dunia pendidikan tidak harus menelan korban bunuh diri.

Banyaknya kasus kekerasan yang terjadi di sekolah menjadikan pendidikan tidak dapat terlaksana secara maksimal. Menurut beberapa ahli kekerasan yang terjadi di sekolah berasal dari tindakan bullying. Menurut Priyatna (2010: 2) "satu dari tiga anak di seluruh dunia mengaku pernah mengalami bullying, baik itu di sekolah, di lingkungan masyarakat maupun di dunia maya”. Begitupun sebaliknya satu dari tiga anak mengaku pernah melakukan tindakan bullying pada temannya. Bullying di sekolah bisa dilakukan oleh individu ke individu, kelompok ke individu atau kelompok ke kelompok. Tak jarang pula terjadi dari guru ke siswa. Tujuannya adalah pelaku ingin menunjukkan kekuatan kepada yang lain. Menurut Sucipto (2012) bullying dapat berbentuk fisik seperti pukulan, tendangan,tamparan, dorongan, serta serangan fisik lainnya. Yang berbentuk non fisik bullying dapat dibedakan menjadi 2 (dua), yaitu verbal maupun nonverbal.

Salah satu contoh kasus bullyingkasus bullying terjadi antara senior dengan adik kelasnya. Kasus itu terjadi pada November 2011, Rh dipukuli seniornya ketika dia kelas I di SMA PL, tapi tidak ditindaklanjuti serius pihak sekolah. Kejadian ini berawal ketika Rh kedapatan tengah berfoto-foto di lingkungan sekolah. Rupanya aksi Rh menyebabkan beberapa seniornya di SMA PL merasa terganggu. Tiga kakak kelas Rh memaksa $\mathrm{Rh}$ masuk ke dalam mobil. Satu orang menyetir berputar-putar. Dua senior lainnya memukuli Rh. Rh dipaksa telentang di bagian tengah mobil. Rusuk Rh retak parah mendekati patah. Setelah dianiaya, Rh takut masuk sekolah. Rh bahkan tidak ikut ujian mid semester dan tidak pernah mau mengatakan identitas ketiga seniornya itu. (http//.kompas.com/kekerasan.masih.terjadi.di.sek olah.htm) yang diunduh tanggal 14 April 2012

Keberadaan layanan Bimbingan Konseling di sekolah yang belum dimanfaatkan siswa secara maksimal, disebabkan karena masih banyak siswa yang belum mengetahui fungsi dan layanan Bimbingan Konseling. Untuk itu penting bagi guru Bimbingan Konseling memberikan informasi mengenai fungsi dan layanan-layanan yang ada di Bimbingan Konseling di sekolah.

Selain kurang informasi mengenai keberadaan Bimbingan dan Konseling, guru pembimbing di sekolah biasanya juga akan memberikan layanan jika telah terjadi suatu permasalahan seperti halnya bullying. Sebelum suatu permasalah itu terjadi seharusnya ada upaya pencegahan terlebih dahulu, karena tindakan bullying biasanya dilakukan secara tertutup dan tidak semua siswa dan guru tahu. Untuk itu salah satu cara yang dapat digunakan yaitu memberikan informasi melalui Bimbingan Klasikal menggunakan teknik diskusi kelompok terhadap siswa mengenai bahaya bullying.

Berdasarkan wawancara dengan koordinator bimbingan dan konseling SMP Muhammadiyah 3 Yogyakarta pada tanggal 16 Mei 2012 dapat disimpulkan bahwa materi bahaya bullying selama ini memang belum dimasukkan dalam layanan dasar bimbingan dan konseling, selama ini memang ketika ada laporan dari siswa, atau indikasi terjadi bullying di sekolah masuk dalam layanan responif

Banyak metode yang ada dalam Bimbingan Klasikal, namun peneliti memilih teknik diskusi kelompok sebagai teknik yang digunakan. Alasan menggunakan teknik diskusi kelompok karena dengan menggunakan teknik diskusi kelompok dalam satu kelas, siswa dibagi menjadi beberapa kelompok untuk membahas masalah yang akan dipecahkan secara bersama. Dalam hal ini peneliti akan memberikan masalah yang terkait dengan bullying. Menurut Muro (dalam Romlah 2006 : 89) “diskusi kelompok tidak hanya untuk memecahkan masalah tetapi juga untuk mencerahkan suatu persoalan, serta untuk pengembangan pribadi”. Siswa dilatih untuk memecahkan masalah bullying yang banyak terjadi di sekolah, selain itu melatih kemampuan sosial siswa jika dipossisikan pada diskusi 
kelompok yang melibtakan beberapa orang di dalamnya.

Teknik diskusi kelompok ini juga digunakan agar pada suatu saat ketika siswa dihadapkan pada permasalahan bullying, siswa tersebut mampu menghadapi dan menyelesaikannya sendiri. Selain itu bimbingan klasikal ini melibatkan seluruh siswa di kelas, sehingga siswa akan mendapat materi yang sama mengenai bullying. Peneliti berharap dengan mendapatkan materi yang sama akan mengurangi tindakan bullying bagi siswa yang pernah melakukan bullying, dan mencegah terjadinya bullying bagi siswa yang belum pernah melakukan tindakan bullying.

Secara operasional rumusan masalah penelitian adalah mengkaji efektivitas penggunaan metode Bimbingan Klasikal dengan teknik diskusi kelompok dalam meningkatkan pemahaman bahaya bullying. Penelitian bertujuan untuk mendeskripsikan efektivitas penggunaan metode Bimbingan Klasikal dengan teknik diskusi kelompok dalam meningkatkan pemahaman bahaya bullying pada siswa kelas VIII di SMP Muhammadiyah 3 Yogyakarta tahun ajaran 2012/2013. Hasil penelitian ini dapat dijadikan sebagai bahan rujukan bagi guru bimbingan dan konseling untuk meningkatkan pemahaman bahaya bullying pada siswa melalui layanan bimbingan klasikal di sekolah

\section{Kajian Literatur}

\section{Bullying dan Bahaya yang Ditimbulkan}

Menurut Priyatna (2010 : 2) bullying yaitu “tindakan yang sengaja oleh pelaku pada korbannya yang dilakukan secara berulang-ulang, dan disadari perbedaan power yang mencolok”. Jadi, menurut Priyatna bullying adalah tindakan dari pelaku yang lebih kuat kepada yang lebih lemah, jika ada perkelahian yang dilakukan antar anak yang memiliki ukuran fisik dan kekuatan yang sama itu bukan termasuk tindakan bullying.

Menurut Olweus (Sanders \& Phye 2004:3) menyatakan bahwa bullying adalah "tindakan siswa yang sedang ditindas atau menjadi korban secara berulang kali dan dari waktu ke waktu secara negatif oleh satu atau lebih siswa lain". Menurut peneliti dapat disimpulkan bahwa bullying adalah tindakan menyakiti seseorang yang ditunjukkan dengan perbedaan kekuatan yang menonjol dan dilakukan secara sengaja serta berulang-ulang baik oleh individu ke individu lain maupun dari kelompok individu ke individu lain.
Pelaku bullying adalah seseorang yang secara langsung melakukan agresi baik fisik, verbal atau psikologis kepada orang lain dengan tujuan untuk menunjukkan kekuatan atau mendemonstrasikan pada orang lain. Tindakan bullying itu berakibat buruk bagi korban, saksi, sekaligus pelakunya itu sendiri. Bahkan efeknya terkadang membekas sampai si anak telah menjadi dewasa. Menurut Priyatna ( 2010 : 4-5) “dampak buruk bullying dapat menimpa korban, pelaku dan juga orang yang menyaksikannya”. Berikut akan dijelaskan dampak buruk dari bullying:

Dampak buruk yang dapat terjadi pada anak yang menjadi korban tindakan bullying, antara lain : 1) Kecemasan, 2) Merasa kesepian, 3) Rendah diri, 4) Tingkat kompetensi sosial yang rendah, 5) Depresi, 6) Simtom psikosomatik, 7) Penarikan sosial, 8) Keluhan pada kesehatan fisik, 9) Kabur dari rumah, 10) Penggunaan alkohol dan obat, 11) Bunuh dari dan 12) Penurunan performasi akademik. Selain itu, dampak buruk yang dapat terjadi pada anak yang menjadi pelaku tindakan bullying, antara lain: 1) Sering terlibat dalam perkelahian, 2) Resiko mengalami cedera akibat perkelahian, 3) Melakuan tindakan pencurian, 4) Minum alkohol, 5) Merokok, 6) Menjadi biang kerok disekolah, 7) Kabur dari sekolah atau minggat, 8) Gemar membawa senjata tajam, 9) Yang terparah : menjadi perilaku tindak kriminal. Dalam sebuah studi, 60 \% dari anak yang biasa melakukan tindakan bullying menjadi pelaku tindakan kriminal sebelum mereka menginjak usia 24 tahun.

Sementara untuk siswa yang biasa menyaksikan tindakan bullying pada kawan - kawannya berada pada resiko : 1) Menjadi penakut dan rapuh, 2) Sering mengalami kecemasan, 3) Rasa keamanan diri yang rendah.

Dampak buruk dari tindakan bullying sangat membahayakan terutama bagi kelangsungan belajar siswa di sekolah, siswa akan sulit mengikuti pelajaran yang diberikan oleh guru. Bahkan tidak hanya di sekolah di lingkungan masyarakat bullying juga ikut andil dalam penyebab tindak kriminal. Tidak hanya itu semua pihak ikut menaggung dampak buruk bullying, tidak hanya korban bahkan pelaku dan siswa yang melihat kejadian bullying itu memiliki dampak yang buruk. Terlebih jika bullying dilakukan terus menerus tentu akan menimbulkan efek yang tidak baik. 


\section{Bimbingan dan Konseling}

Menurut Yusuf (2009 : 37) bimbingan dan konseling merupakan proses pemberian bantuan konselor kepada individu secara berkesinambungan agar mampu memahami potensi diri dan lingkungannya, menerima diri, mengembangkan dirinya secara optimal, dan meyesuaikan diri secara positif dan konstruktif terhadap tuntutan norma kehidupan sehingga mencapai kehidupan yang bermakna, baik secara personal maupun sosial.

Sedangkan menurut Kartadinata (Yusuf Syamsu, 2006 : 38) mengartikan bimbingan dan konseling "sebagai proses membantu siswa untuk mencapai perkembangan secara optimal”.

Sementara menurut Natawidjadja (Yusuf Syamsu, 2006 : 38 ) mengartikan bimbingan dan konseling sebagai suatu proses pemberian bantuan kepada siswa yang dilakukan secara berkesinambungan, supaya siswa tersebut dapat memahami dirinya, sehingga siswa sanggup mengarahkan dirinya dan dapat bertindak secara wajar, sesuai dengan tuntutan dan keadaan lingkungan sekolah, keluarga, masyarakat dan kehidupan pada umumnya.

Berdasarkan pengertian di atas dapat disimpulkan bahwa bimbingan konseling adalah proses pemberian bantuan kepada siswa secara terus menerus agar siswa mampu mengarahkan diri, memahami diri sehingga siswa mampu menyesuaikan diri di lingkungannya. Dilihat dari aspek potensi dan arah perkembangan siswa, menurut Yusuf (2006 : 51) "bimbingan dan konseling dapat diklasifikasikan menjadi 4 bidang yaitu, bimbingan dan konseling akademik, pribadi, sosial, dan karir”.

\section{Peran Bimbingan Konseling dalam Meningkatkan Pemahaman Bahaya Bullying}

Menurut Walgito (2004: 38-39) fungsi bimbingan di sekolah adalah "sebagai fungsi pemahaman, fungsi preventif , fungsi pengembangan, fungsi penyembuhan, fungsi penyaluran, fungsi perbaikan”. Fungsi Pemahaman, yaitu fungsi bimbingan membantu siswa agar memiliki pemahaman terhadap potensi diri dan lingkungannya (pendidikan, pekerjaan, dan norma agama). Berdasarkan pemahaman ini, pembimbing diharapkan mampu mengembangkan potensi dirinya secara optimal, dan menyesuaikan dirinya dengan lingkungan secara dinamis dan konstruktif. Langkah ini dimaksudkan memberikan pemahaman kepada siswa tentang bullying dan segala hal yang terkait di dalamnya, termasuk konsekuensi yang akan diterima siswa dari sekolah jika ia terlibat dalam persoalan bullying. Sehingga siswa dapat memahami bahaya dari bullying melalui bimbingan klasikal.

Fungsi Preventif, yaitu fungsi yang berkaitan dengan upaya pembimbing untuk senantiasa mengantisipasi berbagai masalah yang mungkin terjadi dan berupaya untuk mencegahnya, supaya tidak dialami oleh siswa. Melalui fungsi ini, pembimbing memberikan bimbingan kepada siswa tentang cara menghindarkan diri dari perbuatan atau kegiatan yang membahayakan dirinya. Dalam langkah ini dimaksudkan untuk mencegah timbulnya masalah bullying di sekolah dan dalam diri siswa sehingga dapat menghambat perkembangannya. Untuk itu perlu dilakukan orientasi tentang layanan bimbingan dan konseling kepada setiap siswa. Guru pembimbing juga dapat membuat program-program yang efektif dalam memberantas bullying.

Fungsi Pengembangan, yaitu fungsi bimbingan yang sifatnya lebih proaktif dari fungsi-fungsi lainnya, pembimbing senantiasa berupaya untuk menciptakan lingkungan belajar yang kondusif, yang memfasilitasi perkembangan siswa. Pembimbing beserta staf sekolahan bekerjasama merencanakan dan melaksanakan program bimbingan secara sistematis dan berkesinambungan dalam upaya membantu siswa mencapai tugas-tugas perkembangannya. Dalam hal ini guru pembimbing jelas tidak bekerja sendiri melainkan dengan dibantu berbagai pihak sekolah dalam hal meningkatkan pemahaman bahaya bullying.

Fungsi Penyembuhan, yaitu fungsi bimbingan yang bersifat kuratif. Fungsi ini berkaitan erat dengan upaya pemberian bantuan kepada siswa yang telah mengalami masalah, baik menyangkut aspek pribadi, sosial, belajar, maupun karir. Jika guru pembimbing mengetahui ada siswa yang terlibat dalam permasalahan bullying, maka guru pembimbing harus segera menangani permasalahan ini hingga tuntas. Baik itu penanganan terhadap pelaku, korban, reinforcer yang terlibat bullying. Termasuk juga pengentasan dalam masalah konsekuensi yang akan diterimanya dari sekolah, karena melanggar peraturan dan disiplin sekolah. 
Fungsi Penyaluran, yaitu fungsi bimbingan dalam membantu konseli memilih kegiatan ekstrakurikuler, jurusan atau program studi, dan memantapkan penguasaan karir atau jabatan yang sesuai dengan minat, bakat, keahlian dan ciri-ciri kepribadian lainnya. Selanjutnya yaitu siswa yang telah melakukan bullying disalurkan terhadap segala sesuatu yang positif dari diri siswa, agar tetap utuh, tidak rusak, dan tetap dalam keadaan semula, serta mengusahakan agar hal-hal tersebut bertambah lebih baik dan berkembang.

Fungsi Perbaikan, yaitu fungsi bimbingan untuk membantu siswa sehingga dapat memperbaiki kekeliruan dalam berfikir, berperasaan dan bertindak. Konselor melakukan intervensi (memberikan perlakuan) terhadap siswa supaya memiliki pola berfikir yang sehat, rasional dan memiliki perasaan yang tepat sehingga dapat mengantarkan mereka kepada tindakan atau kehendak yang produktif dan normatif. Bagi anak-anak yang sudah terlibat bullying maka sebagai proses rehabilitasi perlu dilakukan penyaluran minat dan bakat dengan tepat ke dalam berbagai kegiatan-kegiatan ekskul di sekolah, maupun di luar sekolah. Penyesuaian diri siswa dengan lingkungan sosial serta pengembangan diri dalam mengembangkan potensi positifnya juga perlu dilakukan dalam langkah pengentasan.Yang terpenting sekali bagi pelaku bullying adalah perbaikan.

\section{Metode Penelitian}

Metode yang akan digunakan oleh peneliti yaitu menggunakan PTK (Penelitian Tindakan Kelas). Menurut Arikunto (2011 : 209) PTK adalah "kegiatan penelitian bimbingan dan konseling yang dilakukan dengan mencermati proses ketika klien sedang melakukan sesuatu yang diarahkan oleh peneliti”. Makna kelas bukan ruangan berdinding empat sisi, tetapi sekelompok subjek yang sedang belajar hal yang sama, dengan pengajar atau pembimbing yang sama pula.

Variabel yang digunakan dalam penelitian ini ada 2 macam, yaitu variabel bebas dan variabel terikat. Variabel bebas adalah variabel yang mempengaruhi variabel lain, sedangkan variabel terikat adalah variabel yang berubah karena variabel bebas. Variabel Bebas (X) : Bimbingan
Klasikal 2. Variabel Terikat (Y) : Pemahaman Bahaya Bullying.

Subyek penelitian adalah siswa kelas VIII SMP Muhammadiyah 3 Yogyakarta tahun ajaran 2012/2013 yang berjumlah 32 siswa. Instrumen pengumpulan data yang digunakan adalah angket. Sedangkan teknik analisis data untuk menguji perbedaan rerata pre test dan post test setalah dilakukan tindakan menggunakan t-test.

\section{Hasil Penelitian Dan Pembahasan}

Penelitian ini dilakukan untuk mengetahui pelaksanaan bimbingan klasikal dapat meningkatkan pemahaman siswa mengenai bahaya bullying pada siswa kelas VIII SMP Muhammadiyah 3 Yogyakarta tahun ajaran 2012/2013. Untuk itu, peneliti melakukan pengumpulan data dengan cara prosedur ilmiah. Dalam penelitian ini dilaksanakan dua siklus yaitu siklus I dan siklus II. Dari dua siklus tersebut diperoleh sebagaimana Tabel 1

Tabel 1

Kategori Skor Distribusi Frekuensi Data Pemahaman Bahaya Bullying Setelah diberi Tindakan (Post test)

\begin{tabular}{cccc}
\hline Interval & Frekuensi & F \% & Kategori \\
\hline $30-40$ & 23 & $71,875 \%$ & Sangat \\
& & & Tinggi \\
$23-29$ & 6 & $18,75 \%$ & Tinggi \\
$17-22$ & 3 & $9,375 \%$ & Sedang \\
$10-16$ & - & - & Rendah \\
$0-9$ & - & - & Sangat \\
& & & Rendah \\
Total & 32 & $100 \%$ & \\
\hline
\end{tabular}

Tingkat pemahaman siswa tentang bahaya bullying sebelum (pre test) dan sesudah (post test) diberikan layanan bimbingan klasikal ada pergeseran garis yang menunjukkan adanya peningkatan skor pemahaman siswa tentang bahaya bullying sebelum (pre test) dan sesudah (post test) diberi layanan bimbingan klasikal. Sebelum diberi layanan bimbingan klasikal (pre test) sebagaimana Gambar 1, skor siswa yang berada pada kategori sangat rendah berjumlah 0 siswa., pada kategori rendah berjumlah 3 siswa, pada kategori sedang berjumlah 6 siswa, pada kategori tinggi berjumlah 8 siswa, dan kategori sangat tinggi 15 siswa. Setelah diberi layanan bimbingan klasikal (post test) skor pemahaman 


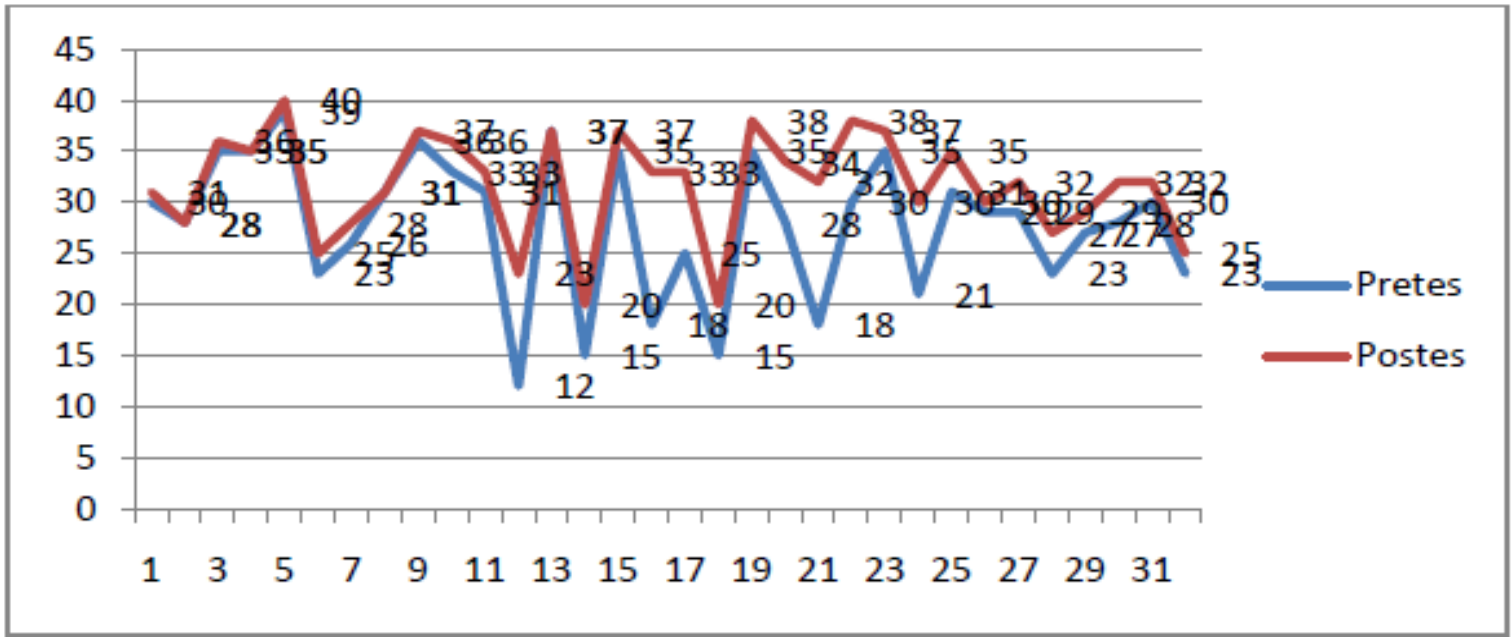

Gambar. 1

Peningkatan Skor Pemahaman Bahaya Bullying Siswa Kelas VIII. 1 Sebelum diberi Layanan Bimbingan Klasikal dan Setelah

siswa mengenai bahaya bullying mengalami peningkatan yang signifikan yaitu skor siswa yang berada pada kategori sangat rendah berjumlah 0 siswa, pada kategori rendah berjumlah 0 siswa, pada kategori sedang berjumlah 3 siswa, pada kategori tinggi berjumlah 6 siswa dan pada kategori tinggi berjumlah 23 siswa.

\section{Simpulan}

Berdasarkan hasil yang diperoleh dari analisis data dan pembahasan maka dapat disimpulkan bahwa siswa antusias dan merasa senang ketika pelaksanaan bimbingan klasikal yang membahas tentang bahaya bullying berlangsung. Penggunaan bimbingan klasikal merupakan strategi yang efektif dan inovatif untuk meningkatkan pemahaman siswa kelas VIII SMP Muhammadiyah 3 Yogyakarta mengenai pemahaman bahaya bullying.

3. Ada peningkatan pemahaman bahaya bullying melalui bimbingan klasikal pada siswa kelas VIII SMP Muhammadiyah 3 Yogyakarta. Siswa yang memiliki pemahaman bahaya bullying pada kategori rendah dan sedang hendaknya lebih aktif dalam mencari berbagai informasi agar pemahamannya terus meningkat, seperti membaca koran, majalah dan melalui internet. Bagi siswa yang berada pada kategori tinggi dan sangat tinggi hendaknya dipertahankan dan diharapkan mampu berbagi informasi dengan teman-temannya yang belum tahu atau kurang tahu mengenai bahaya bullying. Informasi mengenai bahaya bullying tersebut dapat dicari melalui berbagai media yang sekarang sudah semakin maju.

Guru pembimbing dapat memberikan layanan bimbingan klasikal kepada siswa untuk meningkatkan pemahaman bahaya bullying, tentunya harus dilakukan secara konsisten dan optimal. Guru pembimbing hendaknya bekerjasama dengan guru wali kelas dalam memantau siswa di sekolah, dan guru pembimbing hendaknya pula bekerjasama dengan orang tua dalam memantau sikap siswa di rumah.

Guru pembimbing hendaknya melakukan pendekatan lebih menjalin sikap persahabatn dengan siswa sehingga akan terciptanya sikap saling hormat-menghormai. Guru pembimbing harus memiliki sikap ketetgasan pada siswa dengan penuh kasih sayang dan dapat menjadi contoh bagi siswa dalam upaya meningkatkan pemahaman bahaya bullying. Bagi peneliti yang akan datang diharapkan dapat lebih baik lagi dalam melakukan penelitian, misalnya dengan menggunakan strategi-strategi lain yang lebih kreatif dan inovatif. Sehingga penelitian yang dilakukan dapat berjalan dengan lancar dan juga dengan memanfaatkan teknologi yang ada.

. Hasil penelitian ini dapat dijadikan sebagai bahan rujukan bagi guru bimbingan dan konseling dalam upaya meningkatkan pemahaman bahaya 
PRAHARDIKA

bullying pada siswa, dapat melalui layanan bimbingan klasikal di sekolah.

\section{Referensi}

Kompas.com. "Kekerasan Masih Terjadi di Sekolah.”file://G:/skripsi/ Kekerasan.Masih.Terjadi.di.Sekolah.htm. yang diunduh tanggal 14 April 2012, 07.30 WIB.

Priyatna, Andi. (2010). Let's End Bullying (Memahami, Mencegah \& Mengatasi Bullying). Jakarta: Grasindo

Romlah, Tatiek. (2006). Teori dan Praktek Bimbingan Kelompok. Malang: Universitas Negeri Malang.

Sanders, E, Cheryl dan Phye, D, Gary. (2004). Bullying implication for The Clasroom. London : Elsevier Academic Press.

Suharsimi, Arikunto. (2011). Penilaian dan Penelitian Bidang Bimbingan dan Konseling. Yogyakarta : Aditya Media.

Sucipto. (2012). Bullying dan Upaya Meminimalisasikannya PSIKOPEDAGOGIA Bimbingan dan Konseling, 1(1): 19-30.

Yusuf, Syamsu. (2006). Program Bimbingan dan Konseling di Sekolah. Bandung : Pustaka Bani Quraisy

. (2009). Program Bimbingan dan Konseling di Sekolah. Bandung : Rizqi Press

Walgito, Bimo, (2004). Pengantar Psikologi Umum. Yogyakarta : Andi. 